\title{
Detailed mapping of the mass and energy balance of a continuous biomass torrefaction plant
}

\author{
P. Nanou \\ M.C. Carbo \\ J.H.A. Kiel
}

May 2016

ECN-W--16-007 
Research paper

\title{
Detailed mapping of the mass and energy balance of a continuous biomass torrefaction plant
}

\author{
Pavlina Nanou*, Michiel C. Carbo, Jaap H.A. Kiel \\ Energy Research Centre of the Netherlands (ECN), Biomass \& Energy Efficiency, P.O. Box 1, NL-1755 ZG Petten, The Netherlands
}

\section{A R T I C L E I N F O}

\section{Article history:}

Received 14 August 2015

Received in revised form

15 February 2016

Accepted 16 February 2016

Available online 3 March 2016

\section{Keywords:}

Torrefaction

Efficiency

Lignocellulose

Mass balance

Energy balance

Gas analysis

\begin{abstract}
A B S T R A C T
Biomass torrefaction was tested on pilot scale ( $50 \mathrm{~kg} \mathrm{~h}^{-1}$ throughput) for 3 types of wood: spruce, ash and willow at torrefaction temperatures of $250^{\circ} \mathrm{C}-265^{\circ} \mathrm{C}$. Quantitative analysis of process streams was accomplished by utilising on- and off-line analytical methods.

The data obtained from the pilot tests could be very well translated into large-scale operations. A theoretical overall thermal efficiency of $88-89 \%$ was calculated for a large-scale heat-integrated torrefaction process that uses wet woody feedstock containing a mass fraction of $45 \%$ moisture.

These results show that a pilot plant is most suitable not only for exploration of (new) feedstocks but also for generating experimental data that provide valuable information for the design of full-scale plants. The detailed mapping of the mass and energy balances presented in this work can be used further as input for process optimisation, evaluation of commercial viability and techno-economic analyses which can further help in up-scaling and commercialisation of the torrefaction technology.
\end{abstract}

(c) 2016 Elsevier Ltd. All rights reserved.

\section{Introduction}

In all future energy scenarios, biomass and bioenergy play a major role in the transition to a sustainable society and to a circular economy [1]. In these energy schemes, a renewable form of carbon is necessary for the production of solid, liquid and gaseous fuels as well as materials and chemicals. Biomass is the only sustainable feedstock containing carbon that has the potential to be converted into these valuable products.

The types of biomass feedstocks to be utilised preferably in advanced generation of bio-products are residues and wastes, fastgrowing grasses and wood species as well as mixtures of these and, generally, all renewable organic feedstocks that do not interfere with the food chain on any level. These type of feedstocks are often tenacious and fibrous, bulky, non-homogeneous, high in water content, biodegradable and, generally, prone to issues in storage, handling, transportation and processing.

In order to overcome these issues, torrefaction can be applied as a biomass pre-treatment process. Torrefaction is a thermochemical process that, together with a proper densification, can produce a high-quality solid bioenergy carrier, which can serve as a

\footnotetext{
* Corresponding author.

E-mail address: nanou@ecn.nl (P. Nanou).
}

renewable alternative to coal, e.g. in coal-fired power plants [2,3]. Torrefaction in combination with densification transforms the biomass into a more coal-like product which has a higher energy density, is more hydrophobic and is easier to grind than the initial raw biomass $[4,5]$.

Torrefaction is a thermochemical pre-treatment process typically in the temperature range of $200-300{ }^{\circ} \mathrm{C}$. The chemistry behind torrefaction involves mainly the removal of oxygen from the biomass structure after exposure to a hot, oxygen-deficient atmosphere [5-7]. During torrefaction, besides the desired torrefied solid product, also by-products are formed, namely gases, condensable organics and water, which are all contained in the torrefaction gas. Torrefaction gas can be combusted to generate process heat. The torrefied product can be further processed and densified into pellets or briquettes obtaining a solid bioenergy carrier with a high energy density, better adjusted to logistics and end-use requirements [8]. The overall process scheme of the torrefaction concept is presented in Fig. 1. In a large-scale optimised torrefaction scheme, the torrefaction gas can be combusted, if needed together with part of the feedstock (e.g. bark, fines, etc.). This can provide the necessary heat for the torrefaction reactions to proceed but also for pre-drying the feedstock to reduce the initial moisture content.

During torrefaction, mainly the hemicelluloses in the biomass devolatilise as is also illustrated in Fig. 2 by means of thermogravimetric analysis of wood and its constituents [9]. Xylan is one of 


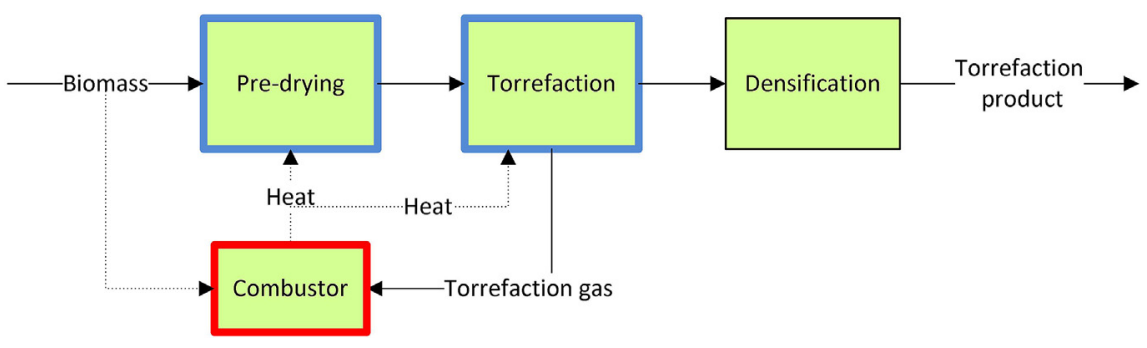

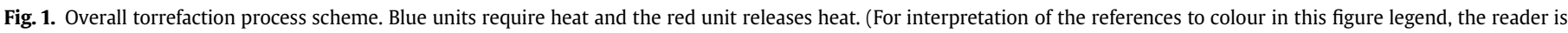
referred to the web version of this article.)

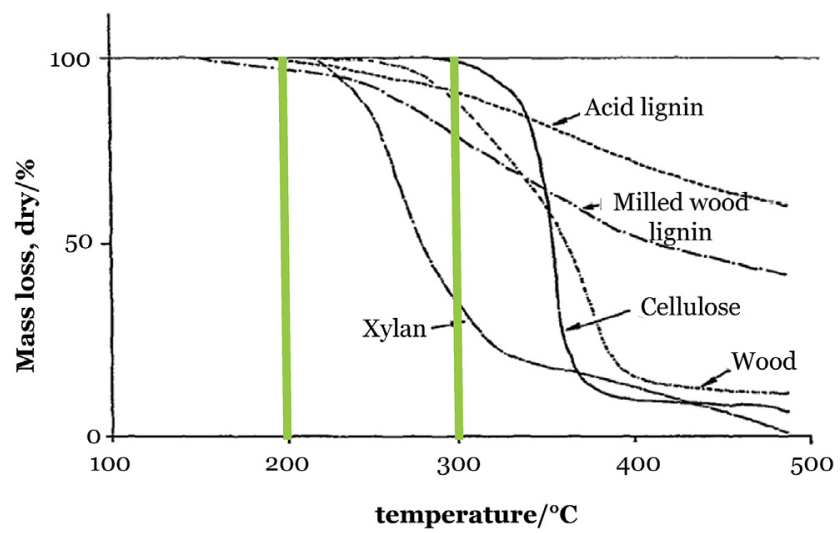

Fig. 2. Devolatilisation pattern of cotton wood and wood constituents. Green lines indicate torrefaction temperature regime. Linear heating rate: $15 \mathrm{~K} \mathrm{~min}^{-1}$. Adapted from Ref. [9]. (For interpretation of the references to colour in this figure legend, the reader is referred to the web version of this article.)

the components of hemicellulose. Decomposition, devolatilisation and depolymerisation are the three major reactions that take place during torrefaction [10]. These reactions are initiated at temperatures around $200{ }^{\circ} \mathrm{C}[9,11]$.

Table 1 summarises the composition of the types of lignocellulosic biomass also used in this present research. Deciduous wood is also known as hardwood and it contains more hemicellulose and less lignin than coniferous wood (softwood). Hemicelluloses are highly temperature sensitive and the extent of wood decomposition also depends on their amount and composition. A xylan-based hemicellulose (present in hardwoods) is more temperature sensitive (i.e., easier to decompose) than a mannan-based hemicellulose (present in softwoods) [12].

Publications on the topic of torrefaction have increased drastically in the past decade which indicates the interest on this subject and the significance of the steps forward that are being taken by

Table 1

Lignocellulose composition of deciduous and coniferous biomass types [20].

\begin{tabular}{lll}
\hline Polymer, mass fraction/\% & Deciduous & Coniferous \\
\hline Lignin & $18-25$ & $25-35$ \\
Cellulose & $40-44$ & $40-44$ \\
Hemicellulose & $15-35$ & $20-32$ \\
Composition Hemicellulose, mass fraction/\% & \\
$4-0$ methyl glucuronoxylan & $80-90$ & $5-15$ \\
$4-0$ methyl glucuronoarabinocyxylan & $<1$ & $15-30$ \\
Glucomannan & $1-5$ & $60-70$ \\
Galactoglucomannan & $<1$ & $1-5$ \\
Arabinogalactan & $<1$ & $15-30$ \\
Other galactose polysaccharides & $<1$ & $<1$ \\
Pectin & $1-5$ & $1-5$ \\
\hline
\end{tabular}

scientists. Most of the research on torrefaction concerns the modelling of torrefaction reaction kinetics and mechanisms [13] as well as process modelling [14,15] and reactor modelling [16]. However, the amount of experimental data that is available on pilot scale torrefaction in continuous reactors appears to be limited. The literature includes results obtained from continuous rotating drum reactors [17-19], an auger screw type reactor [21] and a new torrefaction technology termed REVE (Vibrating Electrical Elevator and Reactor) [22].

Batidzirai et al. [23] modelled mass and energy balances based on experimental data obtained from an existing torrefaction plant. Torrefaction experiments were performed with eucalyptus and straw as feedstocks. However, no experimental data could be provided due to confidentiality reasons. A study by Karlsson [19] used results of $345 \mathrm{~kg} \mathrm{~h}^{-1}$ to $364 \mathrm{~kg} \mathrm{~h}^{-1}$ (rotating drum) torrefaction trials with a wood residue mixture to perform mass and energy balances. Lemus and Gil [21] presented results of their $500 \mathrm{~kg} \mathrm{~h}^{-1}$ pilot plant which they use to determine mass and energy balances, as well as process efficiencies of an integrated torrefaction process based on cereal straw as feedstock. Doassans-Carrère et al. [22] also used results of torrefaction of wood chips on pilot scale $\left(40 \mathrm{~kg} \mathrm{~h}^{-1}\right.$ and $80 \mathrm{~kg} \mathrm{~h}^{-1}$ throughput) to perform a brief techno-economic analysis.

Most of the data available in the literature was generated using small-scale lab equipment and has been further used by researchers to asses torrefaction process performance. Syu and Chiueh [24] used experimental data from the literature on torrefaction of rice straw for their process simulations. They developed an energy and mass flow model which they used for evaluation of system performance. Chen et al. [25] did an energy analysis of the torrefaction of micro-alga residues using data obtained from their lab-scale experimental set-up. They introduced an index of relative energy efficiency (REE) to evaluate the energy utilisation performance in such a torrefaction system. Granados et al. [26] performed thermogravimetric analyses (TGA) on a variety of feedstocks (sugarcane bagasse, banana rachis, rice husk, palm oil fibre, sawdust and coffee waste). These data were used to perform an energy and exergy analysis in order to calculate the respective efficiencies. Van der Stelt in his thesis [27] uses experimental results obtained from his lab-scale torrefaction experiments with beech wood to perform mass and energy balances in an attempt to calculate the heat of reaction.

The aim of this work is to aid to the expansion of publically available experimental data on continuous pilot torrefaction processes. Additionally, we demonstrate how process flows of a pilot plant can be quantified by using on- and off-line analytical methods. The detailed mapping of the mass and energy balances presented in this work are of great significance for process optimisation, evaluation of commercial viability and techno-economic analyses which can further help in up-scaling and commercialisation of the torrefaction technology. 


\section{Materials and methods}

\subsection{Materials}

Three different wood types were used in the pilot torrefaction tests described in this work, namely ash, spruce and willow wood. The elemental analyses of the raw and torrefied wood samples along with the calculated higher heating value (HHV) are presented in Table 2. The elemental analysis was performed with the Element Analyser FLASH 2000 (Thermo Scientific) and the ash content was determined using a Nabertherm LV5/11/B180 oven. CHN content was determined according to EN 15104 and the ash content was defined according to EN 14775. The oxygen content was also analysed and therefore, the sum of elements does not add up to exactly $100 \%$. The higher heating value (HHV) of the wood samples was calculated according to the Milne formula [28].

Debarked and chipped ash and spruce wood were obtained from Van den Broek B.V. (The Netherlands). The wood chips were delivered in dimensions of $>2 \times 2 \times 2 \mathrm{~mm}$ to $\leq 40 \times 40 \times 15 \mathrm{~mm}$. The ash wood was of the family Olacaceae of the genera Fraxinus excelsior. The spruce wood was of the Picea family of the genera Picea abies. These two wood species were used for the torrefaction tests in order to compare the torrefaction behaviour between a hardwood (ash) and a softwood (spruce).

The willow wood was Short Rotation Coppice (SRC) willow of the Salix family and the genera Salix viminalis obtained from SGB (UK). It consisted of small chips and branches with bark of the following dimensions: $>2 \times 2 \times 2 \mathrm{~mm}$ to $\leq 40 \times 10 \times 10 \mathrm{~mm}$. Willow wood is a hardwood, but SRC willow was specifically chosen because it contains bark and smaller particle sizes of wood and is in general a different feedstock type compared to earlier tested standard clean wood chips in the pilot plant.

Spruce and willow wood were torrefied in the pilot plant at $260{ }^{\circ} \mathrm{C}$ and ash wood at $250{ }^{\circ} \mathrm{C}$ and $265{ }^{\circ} \mathrm{C}$. Initial screening torrefaction experiments had been performed in a TGA apparatus and a batch torrefaction reactor in order to define the torrefaction temperature for the pilot tests. The torrefaction temperatures in the pilot plant were chosen so that dry mass yields would be between $73 \%$ and $79 \%$ based on these initial screening tests. The additional test for ash wood was performed in order to record and observe differences for this specific wood type with varying torrefaction temperature.

\subsection{Pilot plant layout and test procedures}

The torrefaction pilot plant at ECN's research facilities has a nominal production capacity of approximately $50 \mathrm{~kg} \mathrm{~h}^{-1}$. It is based on a moving-bed reactor concept with direct heating of the biomass by recycled product gas. Numerous pilot tests have been successfully completed with more than 10 different biomass species since its first start-up in 2008. It has been operated for more than $2500 \mathrm{~h}$, having produced over 85 tonnes of torrefied material. The tests presented in this work are the first tests where all process flows of

Table 2

Elemental analysis and heating value of the tested raw and torrefied materials (on dry basis); $\mathrm{C}, \mathrm{H}, \mathrm{N}, \mathrm{O}$ and ash expressed in mass fraction percentages.

\begin{tabular}{lllllll}
\hline Type of biomass & $\mathrm{C} / \%$ & $\mathrm{H} / \%$ & $\mathrm{~N} / \%$ & $\mathrm{O} / \%$ & $\mathrm{Ash} / \%$ & $\mathrm{HHV} / \mathrm{MJ} \mathrm{kg}^{-1}$ \\
\hline Spruce raw & 48.0 & 6.3 & 0.11 & 46.0 & 0.4 & 19.2 \\
Spruce 260 & 52.0 & 6.1 & 0.08 & 42.0 & 0.4 & 20.7 \\
Ash raw & 48.0 & 6.2 & 0.15 & 47.0 & 0.6 & 18.9 \\
Ash 250 & 52.0 & 6.0 & 0.16 & 41.0 & 0.9 & 20.7 \\
Ash 265 & 53.0 & 6.0 & 0.15 & 41.0 & 0.9 & 21.1 \\
Willow raw & 48.0 & 6.2 & 0.36 & 44.0 & 2.0 & 19.2 \\
Willow 260 & 54.0 & 5.7 & 0.42 & 38.0 & 1.9 & 21.3 \\
\hline
\end{tabular}

the pilot plant were analysed and quantified.

The torrefaction pilot plant consists of three main sections each occupying one floor in a three-storey building. These sections are: (1) the feeding and drying section, (2) the torrefaction section and (3) the torrefied product collection section, which can all be seen in Fig. 3.

If required, the biomass is pre-dried by a subcontractor to a moisture mass fraction of $10-20 \%$. The wood is contained in cubic boxes which are hoisted by a crane to the top floor of the pilot facility where they are tipped onto a belt conveyor. The top part of the drying section has a sluicing system which allows batches of ingoing wood chips to be flushed with nitrogen (flow set by mass flow controller) before being released into the drying unit. Wood batches of 5-10 kg are fed during each cycle, depending on the bulk density of the biomass. All operating conditions are selected based on the moisture content and the desired torrefaction recipe for the selected feedstock. The biomass is heated up to $150-200{ }^{\circ} \mathrm{C}$ by direct contacting with recycled steam of a maximum temperature of $220^{\circ} \mathrm{C}$.

Subsequently, the dried biomass enters the torrefaction section of the pilot plant reactor. The wood is heated directly by a recycled torrefaction gas stream at a temperature of $250-340{ }^{\circ} \mathrm{C}$ so that the torrefied wood can reach a temperature of $240-320{ }^{\circ} \mathrm{C}$ at the bottom of the reactor. The recycled gas streams in the drying and torrefaction section are recirculated with use of a blower and preheated in heat exchangers with an electrically heated thermal oil system. The surplus steam and torrefaction gas are burnt together in a combustor and the flue gas is vented to the stack. The torrefied material is extracted from the bottom of the reactor with a shredder and via screw conveyors it is transported and stored in metal storage vessels situated on the ground floor, where it is allowed to cool down under a nitrogen purge (flow set by mass flow controller). The solids residence time during torrefaction is regulated by the frequency controller of the shredder at the bottom of the reactor, and is typically $30 \mathrm{~min}-40 \mathrm{~min}$.

In case densification (pelletisation or briquetting) of the torrefied material is required, the material is transported to a pelleting/briquetting facility. During steady-state operating conditions, condensate samples were collected from the torrefaction gases and produced permanent gases were continuously analysed by on-line gas analysis. Details on the methods and equipment used is described in the next section. A simplified block diagram of the pilot plant along with the various sampling points is given in Fig. 4.

Table 3 gives an overview of the pilot tests performed in this study. The torrefaction conditions applied, average moisture content, throughputs and test durations are listed.

During the tests, raw biomass input was determined at steadystate conditions by recording the time it takes to feed a cubic box of known net mass of wood. Steady-state operation is characterised by steady temperature profiles in the dryer and torrefaction reactor accompanied by a steady pressure drop in the system. The torrefied product output flow is controlled by calibrating the shredder throughput using a frequency controller. The moisture content of the fed wood was measured gravimetrically after drying samples (obtained from different feedstock cubic boxes) overnight in an oven at $105^{\circ} \mathrm{C}$.

The mass yield $\left(\mathrm{M}_{\mathrm{y}}\right)$ expresses the mass percentage of the original dry biomass that is retained in the solid torrefied product and is defined as:

$M y(\%)=\frac{M_{\text {wood }}^{d r y}}{M_{\text {torr }}} 100 \%$ 


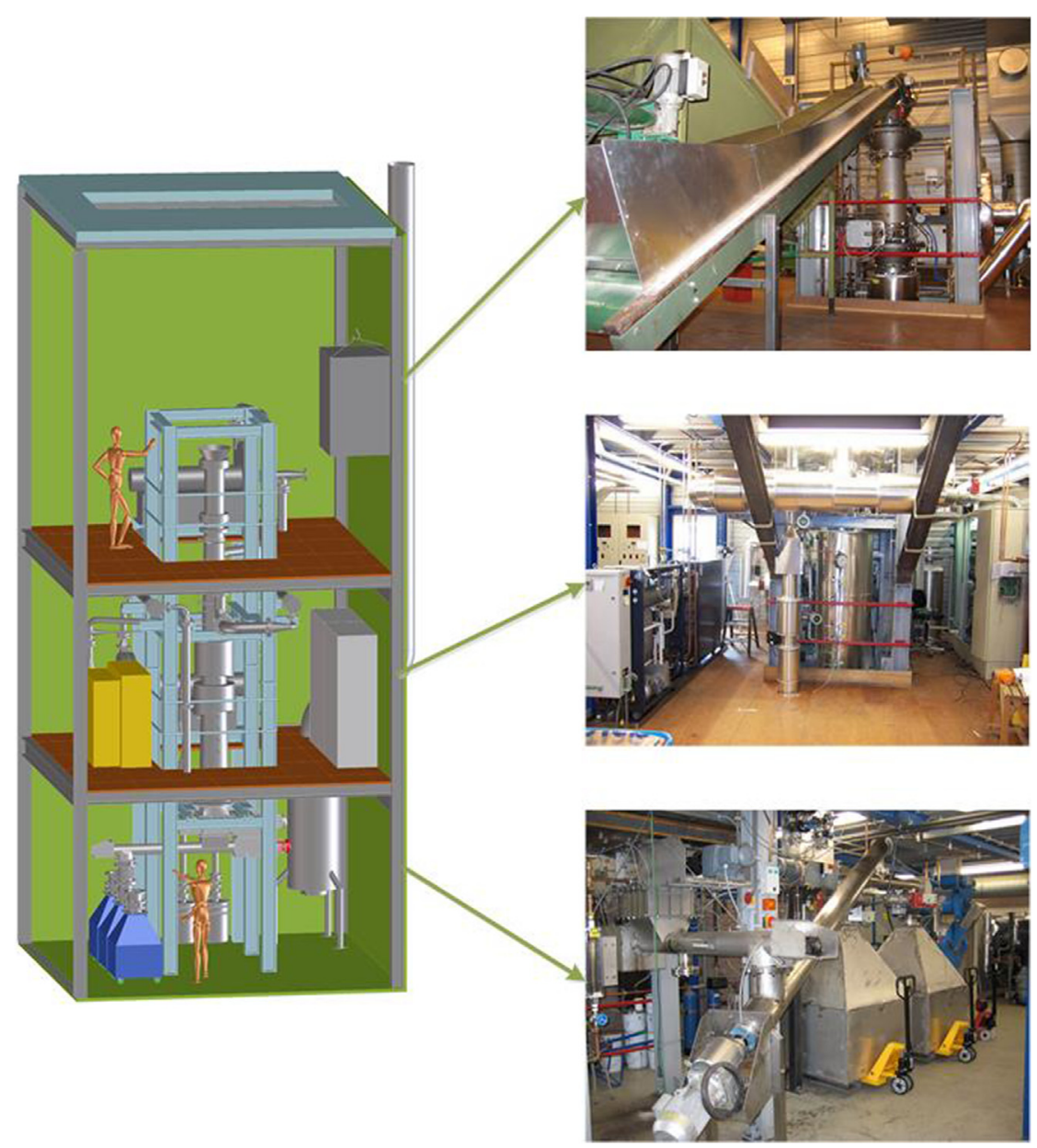

Fig. 3. Torrefaction pilot plant at ECN. Top: Feeding and drying section, Middle: Torrefaction reactor, Bottom: Product collection.

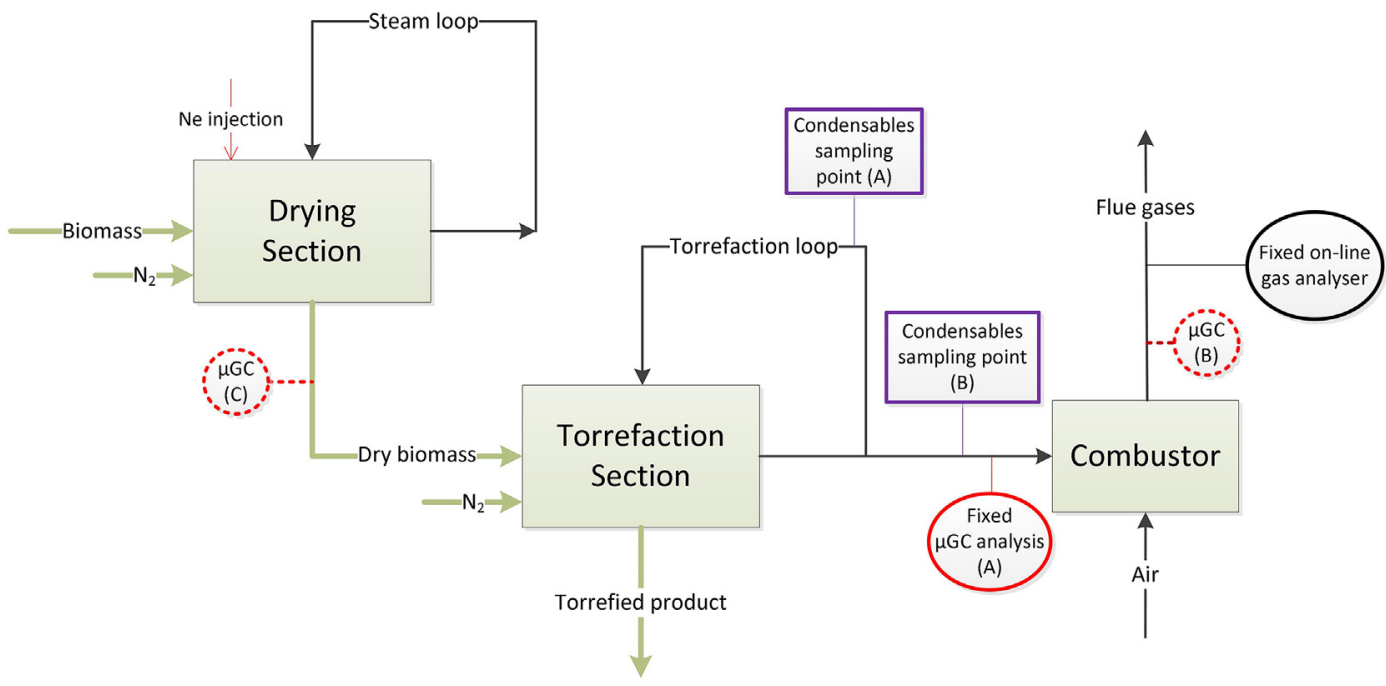

Fig. 4. Simplified block diagram of ECN's pilot plant including on-line sampling points. Sampling points illustrated with a dotted line ( $\mu \mathrm{GC}$ (B) and $\mu \mathrm{GC}$ (C)) are not fixed sampling point positions (optional sampling points for micro-GC analysis).

where $\mathrm{M}^{\mathrm{dry}}{ }_{\text {wood }}$ is the mass flow of the dry raw wood in $\mathrm{kg} \mathrm{h}^{-1}$ and $\mathrm{M}_{\mathrm{torr}}$ is the mass flow of the produced torrefied solid in $\mathrm{kg} \mathrm{h}^{-1}$.

The energy yield $\left(\mathrm{E}_{\mathrm{y}}\right)$ expresses the percentage of the energy present in the original dry biomass that is retained in the solid torrefied product and is defined as:

$E y(\%)=M_{y} \frac{E_{\text {wood }}^{\text {dry }}}{E_{\text {torr }}} 100 \%$

where $E^{\mathrm{dry}}$ wood is the lower heating value (LHV) of the dry original 
Table 3

Overview of pilot plant tests.

\begin{tabular}{|c|c|c|c|c|c|c|}
\hline $\begin{array}{l}\text { Type of } \\
\text { biomass }\end{array}$ & $\begin{array}{l}\text { Torrefaction } \\
\text { temperature } /{ }^{\circ} \mathrm{C}\end{array}$ & $\begin{array}{l}\text { Torrefaction residence } \\
\text { time/min }\end{array}$ & $\begin{array}{l}\text { Wet biomass input/ } \\
\mathrm{kg} \mathrm{h}^{-1}\end{array}$ & $\begin{array}{l}\text { Average moisture mass } \\
\text { fraction/\% }\end{array}$ & $\begin{array}{l}\text { Torrefied biomass production/ } \\
\mathrm{kg} \mathrm{h}^{-1}\end{array}$ & $\begin{array}{l}\text { Pilot test } \\
\text { duration/ } \\
\text { h }\end{array}$ \\
\hline Spruce wood & 260 & 32 & 48.4 & 12.6 & 33.4 & 36.9 \\
\hline Ash wood & 250 & 39 & 52.6 & 12.7 & 35.4 & 38.6 \\
\hline Ash wood & 265 & 43 & 53.2 & 12.2 & 34.3 & 39.0 \\
\hline Willow wood & 260 & 34 & 46.8 & 12.3 & 30.6 & 20.9 \\
\hline
\end{tabular}

wood in $\mathrm{MJ} \mathrm{kg}^{-1}, \mathrm{E}_{\text {torr }}$ is the lower heating value (LHV) of the

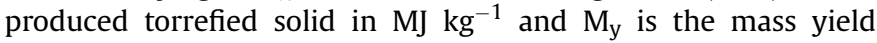
calculated by eq. (1).

The lower heating value (LHV) of the dry original wood and torrefied wood was calculated according to the following equation:

$L H V=H H V-(2.443 \cdot 8.936 \cdot H / 100)$

where HHV is the calculated higher heating value in $\mathrm{MJ} \mathrm{kg}^{-1}$ (Milne formula) and $\mathrm{H}$ is the hydrogen content of the dry or torrefied wood expressed in mass percentage as obtained from the analyses in Table 2.

\subsection{Sampling and analysis of condensables (organic vapours and water) in torrefaction gas}

At steady-state operation of the pilot plant, sampling for quantification of the condensable torrefaction products was performed according to the technical specification CEN/TS 15439 [29]. Although this technical specification has been developed for sampling and analysis of biomass gasification tars, it has been used successfully in low temperature pyrolysis tests as well [30].

The condensables were sampled at two sampling points as indicated in Fig. 4: (A) torrefaction gas loop and (B) torrefaction gas flow to the combustor. One sample serves as a duplicate of the other. Fig. 5 shows the schematic of the sampling train used. All the impinger bottles in the set-up initially contained isopropyl alcohol (IPA). From previous work by Neeft et al. [31] it has been shown that IPA is a reasonably effective solvent for fresh condensates. The impingers were weighed before and after sampling to quantify the net amount of condensables in the gas stream.

The measurements consisted of sampling a small $\left(2-3 \mathrm{~L} \mathrm{~min}^{-1}\right)$ slip-stream from the torrefaction gas and quenching it in a train of six impinger bottles filled with a known amount of IPA at $+40{ }^{\circ} \mathrm{C}$ (impinger bottles 1,2 and 4 kept in a water bath) and $-20^{\circ} \mathrm{C}$ (impinger bottles 3, 5 and $6 \mathrm{kept}$ in an ethylene glycol bath). The specific sequence of the liquid IPA-quench was chosen after research performed concerning collection efficiency of tars in different impinger trains. Collection efficiency is influenced by type of solvent, solvent temperature, the number of temperature gradients in the train, gas flow rate, wash bottle design, presence of glass frits, pressure drop over the sampling train and tar composition. Detailed results of this research are available at ref [32]. The specific sampling train that was utilised is very effective in capturing both condensable volatiles and aerosols (>99\%).

After sampling for about 50-90 min, the contents of the impingers were collected, mixed and analysed off-line by a gas chromatograph coupled to a mass spectrometer (GC-MS) for quantification of specific organic components and by Karl-Fischer titration for water content determination. The gas chromatograph used was a TRACE GC ULTRA (Thermo) with a slit/splitless injector and the coupled mass spectrometer was a TRACE DSQII (Thermo). The Karl-Fischer titration apparatus used was a $684 \mathrm{KF}$ Coulometer (Metrohm).

\subsection{Sampling and analysis of non-condensables (gases) in torrefaction gas}

Continuous gas sampling was done at two fixed sampling points: (A) of the torrefaction gas before the combustor by microGC and (B) of the flue gases by on-line gas analysis, also illustrated in Fig. 4. The micro-GC could be placed and moved where needed (sampling points (B) and (C) in Fig. 4).

Neon was used as a tracer gas to quantify the gas flows in the pilot plant. A known flow of neon gas was injected in the drying section of the pilot plant and the downstream gas flows could be quantified: the gas flow from the drying section to the torrefaction section ( $\mu \mathrm{GC}$ sampling point $(C)$ ), the torrefaction gas flow to the combustor ( $\mu \mathrm{GC}$ sampling point $(\mathrm{A})$ ) and the flow of the flue gases after the combustor ( $\mu \mathrm{GC}$ sampling point $(B))$.

The GC used was a CP4900 micro-GC with four columns running on helium carrier gas with TCD detectors [Ch1: Molsieve $\left(@ 80^{\circ} \mathrm{C}\right)$, Ch2 + 3: PoraPlot PPU (@60 $\left.{ }^{\circ} \mathrm{C}\right), \mathrm{Ch} 4$ : CP-wax-52CB $\left.\left(80{ }^{\circ} \mathrm{C}\right)\right]$. The micro-GC could analyse the following gases: $\mathrm{Ne}, \mathrm{H}_{2}, \mathrm{Ar} / \mathrm{O}_{2}, \mathrm{~N}_{2}, \mathrm{CH}_{4}$, $\mathrm{CO}, \mathrm{CO}_{2}, \mathrm{C}_{2}$ (ethane, ethylene and acetylene), $\mathrm{H}_{2} \mathrm{~S}, \mathrm{C}_{6} \mathrm{H}_{6}$ (benzene) and $\mathrm{C}_{7} \mathrm{H}_{8}$ (toluene). The on-line gas analyser contained different measuring cells that could detect $\mathrm{CO}, \mathrm{CO}_{2}, \mathrm{NO}, \mathrm{NO}_{2}$ and $\mathrm{O}_{2}$ in the flue gas.

\section{Results and discussion}

\subsection{Mass and energy yields of torrefaction products}

From the measured and analysed data of the different pilot torrefaction tests, mass and energy balances could be obtained. The results for product mass and (normalised) energy yields are presented in Fig. 6. At the applied torrefaction temperatures, the mass yield of torrefied wood ranged between $73 \%$ and $77 \%$ for the hardwood species tested (ash and willow) and is 79\% for the softwood specie (spruce). The mass yield obtained with torrefaction depends on applied temperature and residence time. Therefore, different types of reactors or set-ups used throughout the literature for torrefaction tests result in mass yields varying widely from $50 \%$ to $97 \%$ [33]. Also, the mass yield has been reported by Prins et al. [34] to depend on the type of biomass material.

When these results are compared to similar pilot tests performed in the past with similar softwood and hardwood chips, the mass yields of the solid products are within a standard deviation of $1.6-2 \%$. Therefore, reproducibility of the pilot plant results is very good and the differences discussed in this section are considered significant.

In a closing mass balance, the product mass yields would sum up to $100 \%$, which is not the case in Fig. 6. Actual mass balance closures varied between $92 \%$ for ash torrefied at $250{ }^{\circ} \mathrm{C}-104 \%$ for ash torrefied at $265{ }^{\circ} \mathrm{C}$. The main reason for this is that process flows slightly fluctuate during a torrefaction pilot test and average overall values have been obtained and further used in calculations. Biomass throughput is the parameter that can be monitored most accurately, since wet wood input and torrefied wood output are 


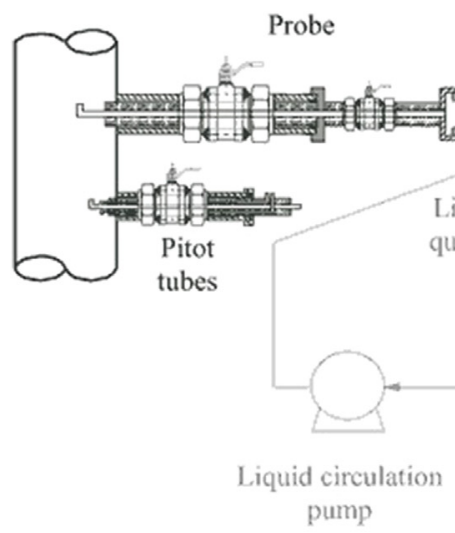

Particle filter (heated)

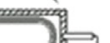

$\sqrt{2}$

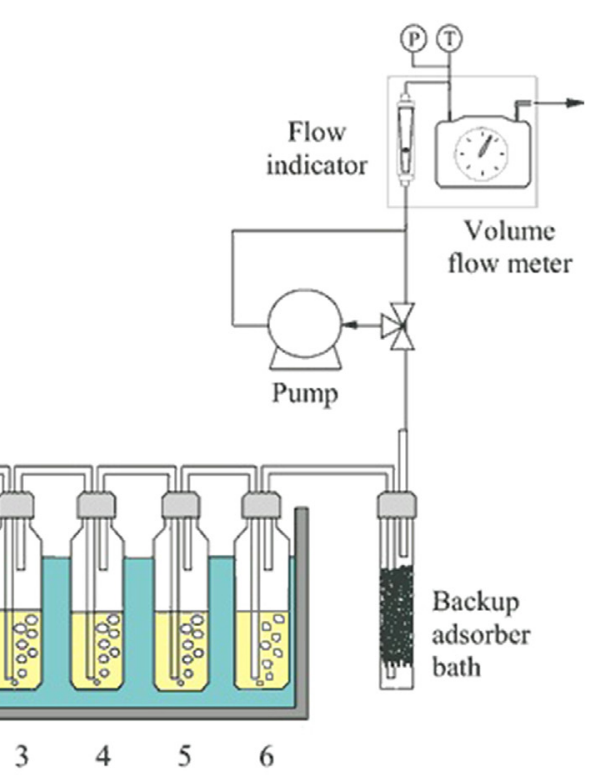

Gas washing bottles

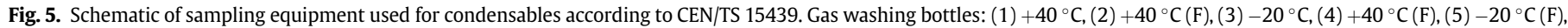
(6) $-20{ }^{\circ} \mathrm{C}(\mathrm{F})$. F designates a glass frit to capture aerosols.
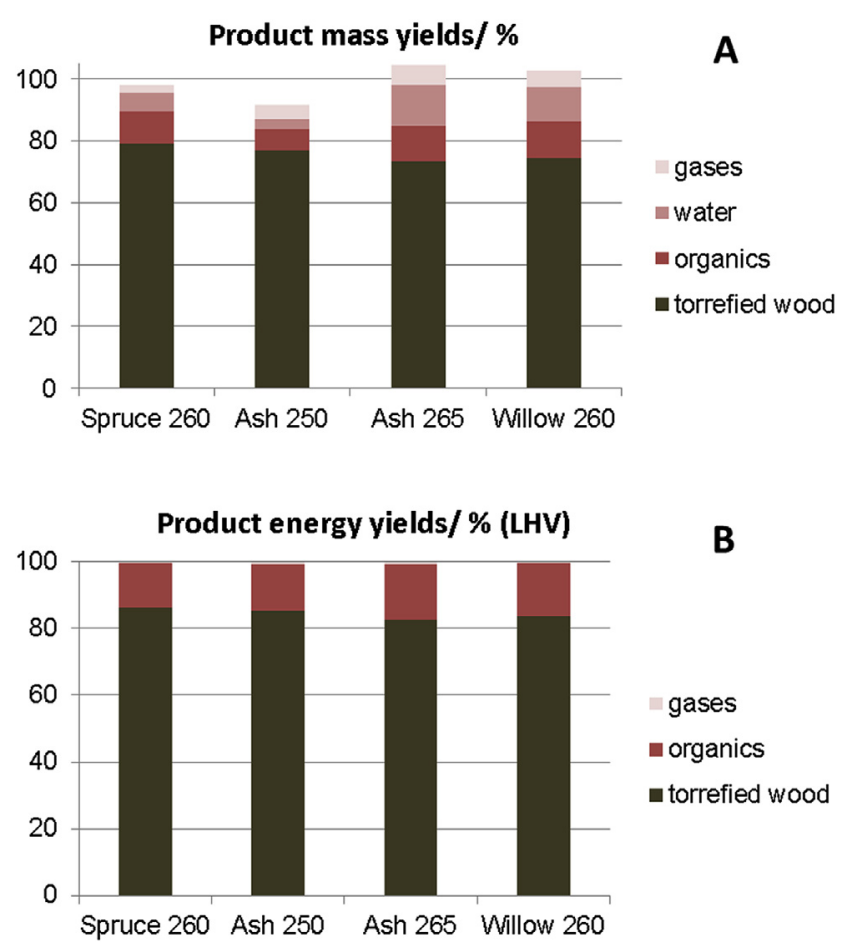

Fig. 6. Product mass (A) and normalised energy yields (B). Data from on- and off-line measured and analysed data.

constantly recorded and the torrefied solid product comprises the largest fraction of the products. However, although the gas analysis data (condensables measurements and flow quantification) are measured during stable plant operation, they represent one moment during a test and give quantitative data for that particular moment. Therefore, outgoing flows of torrefaction gas can be slightly over- or under-estimated. Nevertheless, this mismatch is considered reasonable and acceptable for this scale of torrefaction tests.

The energy yields presented in Fig. 6 have been calculated assuming a closing mass balance and are therefore given as "normalised" energy yields. The mass balance was corrected for the over- or under-estimated fraction of products and these amounts were ascribed to and proportionally distributed among the gasphase products (condensables and permanent gases).

The energy yield of the torrefied solid product generally varies between $83 \%$ and $86 \%$. The absolute amounts of the organics were calculated by difference, assuming a closing mass balance. The heating value of the sum of total volatiles (torrefaction gas) released during torrefaction (water, $\mathrm{CO}, \mathrm{CO}_{2}$ and organics) was calculated by difference from the mass and energy balances and it was found to be in the range of $12-14 \mathrm{MJ} \mathrm{kg}^{-1}$ (HHV basis) or 11-12 $\mathrm{MJ} \mathrm{kg}^{-1}$ (LHV basis). This is in agreement with values reported by Bates and Ghoniem [13].

During torrefaction, the loss of light volatile components causes the $\mathrm{O} / \mathrm{C}$ ratio in the solids to decrease and therefore, the energy density of the torrefied wood on a mass basis increases. The loss and further decomposition of the carboxyl groups from hemicellulose and removal of methoxyl-type groups from lignin and (to a lesser extent) thermal cracking of the carbonyl and carboxyl group of cellulose are the main sources of mass loss during torrefaction [35]. The organics that are released during torrefaction mainly comprise acetic acid and methanol. These two components along with water are the main decomposition products of hemicellulose. The main permanent gases that are released are $\mathrm{CO}_{2}$ and $\mathrm{CO}$. The gas composition of the torrefaction gas product is further discussed in Section 3.3.

During the pilot tests, no signs of exo- or endo-thermicity could be observed.

\subsection{Organics in torrefaction gas}

As presented in Section 3.1, the organics constitute the most significant fraction of the torrefaction gas from an energy content 
point of view (Fig. 6). Therefore, special attention is given in this section to the organics characterisation.

Fig. 7 shows a picture made of one of the two impinger trains after condensables sampling from the torrefaction gas during the spruce test at a torrefaction temperature of $260{ }^{\circ} \mathrm{C}$. The two impinger trains look very similar after sampling, therefore, only one of the two is shown here.

Initially, the impingers contain equal amounts of IPA (isopropyl alcohol) and after sampling the impingers contain IPA, organics, water and some dust particles. As soon as the sampling was initiated, a thick, white mist was visible in the first impinger and it disappeared in downstream impingers. The IPA solvent is actually colourless, so the change in solvent colour to brown/orange and yellow is a result of capturing condensables/aerosols. This effect was more pronounced for the first two bottles, in which some black/brown light precipitate was sometimes noted as well. Overall, the liquid distribution over the two impinger trains at the two sampling points was similar, which was expected since the two sampling points serve as a duplicate of each other in terms of condensables concentration in the gas stream.

The liquids of the six impingers were mixed and this mixture was analysed by GC-MS, the results of which are shown in Fig. 8. The results are expressed per kg of dry wood input. In total, 57 components could be identified and quantified by GC-MS. However, this represents only a fraction of the produced organic components and this fraction is given in Fig. 8 as well. These values were estimated by comparing the total amount of organics analysed by GC-MS to the total amount of organics that could be condensed during sampling. Separation of components by GC is not suitable for oligomeric compounds and components of high molecular mass because of their low vapour pressure. Therefore, the components present in the torrefaction gas that could not be analysed by GC-MS are most probably heavier pyrolytic tars and other organic compounds.

For spruce, most of the detectable fraction are $C_{2}-C_{4}$ oxygenated compounds, mainly methanol, 1-hydroxy-2-propanone and 2hydroxyacetaldehyde. For the hardwoods tested (ash and willow) the largest detectable fraction is comprised of carboxylic acids, mainly acetic acid. All of the above components are mainly derived from the decomposition of hemicellulose in the wood and concentrations are higher for hardwood species (ash and willow) than for softwood. This finding supports the data described in Section 1.1, where hardwood is found by researchers to decompose to a larger extent than softwood at the same torrefaction temperature, since it contains more temperature-sensitive hemicellulose. This is especially profound in the lower temperature torrefaction regime which is studied in this work.

Additionally, phenols are the main decomposition products of

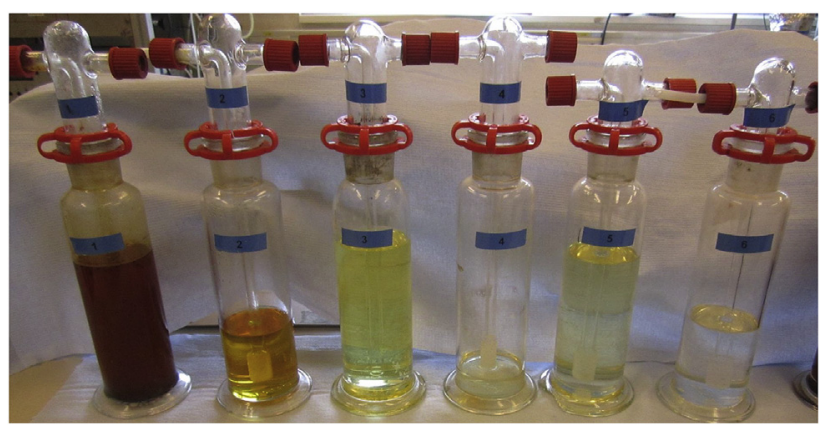

Fig. 7. Impinger train after sampling of condensables during torrefaction of spruce wood at $260{ }^{\circ} \mathrm{C}$. The layout of the impingers, from left to right, corresponds to the sampling layout shown in Fig. 5.

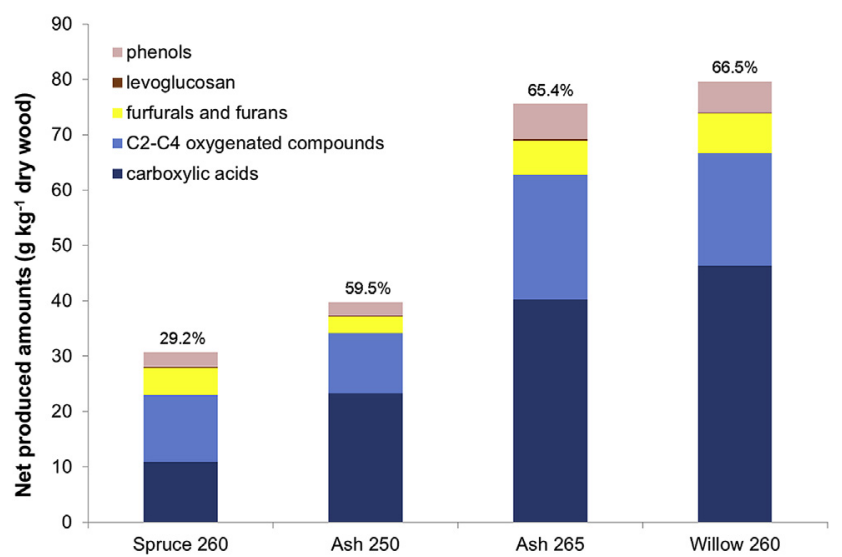

Fig. 8. Net amounts of analysed organics in torrefaction gas. Percentages refer to the fraction of the total organics that could be analysed by GC-MS.

lignin and when comparing phenol production among the tested wood species, it can be noted that this is higher for the hardwoods than for the softwood tested. This signifies that in the $250{ }^{\circ} \mathrm{C}-265{ }^{\circ} \mathrm{C}$ temperature range, hardwood lignin also decomposes to a larger extent than softwood lignin. This is in accordance with previous experimental observations at ECN to be published elsewhere.

What can be noted in the case of ash wood is that a higher torrefaction temperature leads to an increase in GC-detectable organic compounds, probably because of more extensive decomposition of biomass components with increasing temperature, while the composition remains similar. An increased production of torrefaction gas with increasing torrefaction temperature was prominent during pilot plant operation since the downstream combustor required a higher air flow to burn off the excess gas. Also, the total amount of identified species derived from softwood is much smaller than that from hardwood. These trends are in agreement with recently published research supporting that many terpenes and terpenoids are produced during torrefaction of pine. These components could not be trapped by condensation but by utilising solid-phase micro-extraction (SPME fibre) [36].

Levoglucosan is mainly a decomposition product of cellulose and is therefore useful as an indicator of the extent of cellulose decomposition. In our case, the small amounts detected in the torrefaction gas for all tests indicate that cellulose probably remained largely in an undevolatilised state in the torrefied product. This is in agreement with results published by Lv et al. [37] and Park et al. [38].

\subsection{Permanent gases}

Fig. 9 shows the results of the (permanent) gas analysis for the four pilot tests for gas sampling points (A), (B) and (C) as these were depicted in Fig. 4 in Section 2.2. Sampling point (A) gives the gas composition of the produced torrefaction gas, sampling point (B) gives the composition of the flue gases after the combustor and sampling point (C) shows the composition of the gases flowing from the drying section to the torrefaction reactor. Gas concentrations are expressed on dry gas basis and these represent average values during steady-state operation. The balance is mostly $\mathrm{N}_{2}$ (77-90\% in torrefaction gas, $78-84 \%$ in flue gas and $97-98 \%$ in the dryer gas).

The main gases produced by torrefaction are $\mathrm{CO}_{2}$ and $\mathrm{CO}$. The first is a product of decarboxylation of acid groups attached to hemicellulose. $\mathrm{CO}$ is shown in the literature to be either a product of 

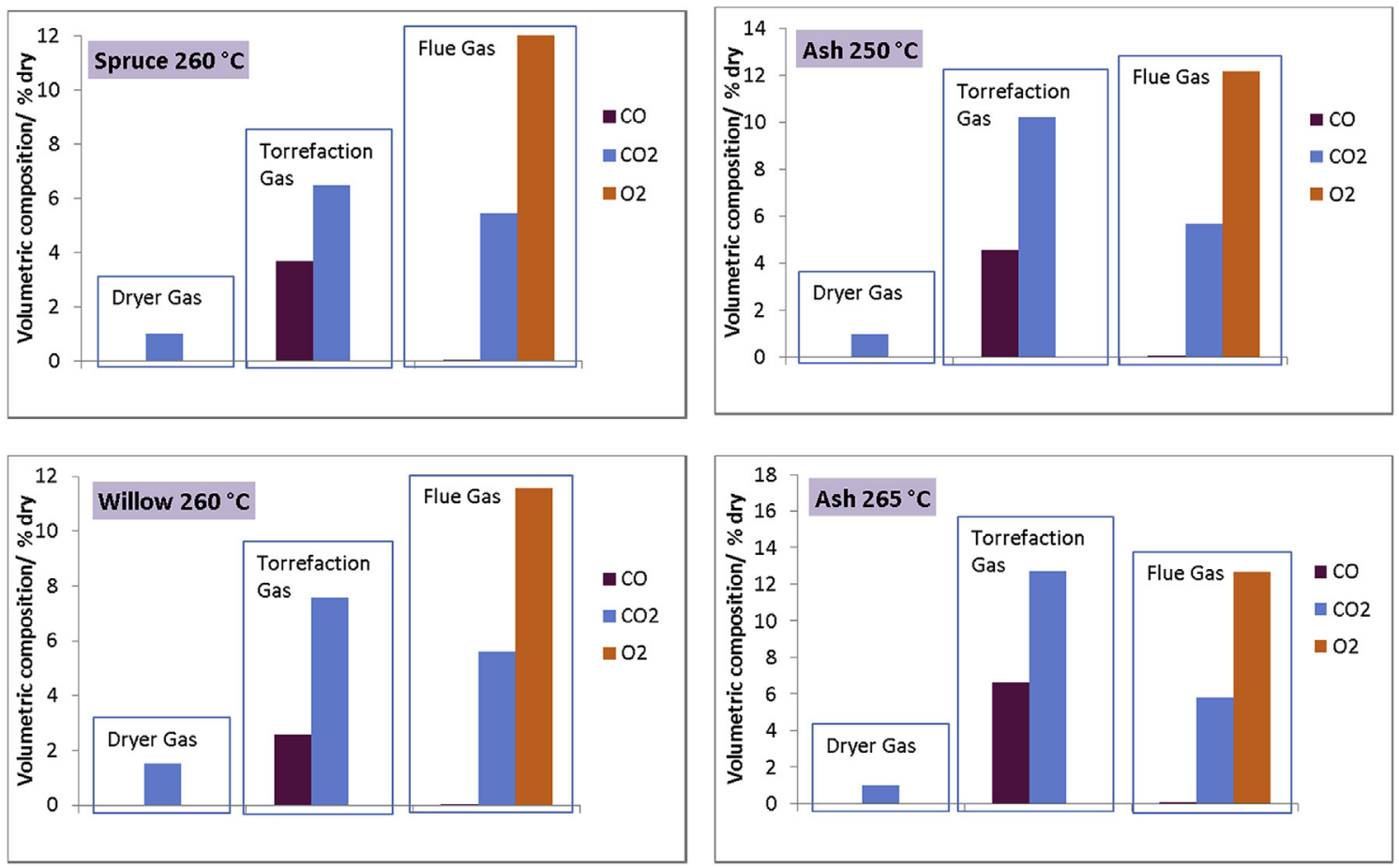

Fig. 9. Dry (permanent) gas composition of the torrefaction and flue gases as measured during the pilot tests. Concentrations represent average values.

steam and carbon dioxide reactions with char [6,26] or a xylan decomposition product at low torrefaction temperatures [33]. The flue gas consists mainly of $\mathrm{O}_{2}$ and $\mathrm{CO}_{2}$, since an excess of air is used in the combustor unit of the pilot plant. The higher concentrations of $\mathrm{CO}$ and $\mathrm{CO}_{2}$ in the torrefaction gas give a good indication of a higher amount of torrefaction gas being produced. This variation in gas composition is, on the other hand, not observed for the flue gas because combustion air flow is regulated based on torrefaction gas production leading to similar flue gas compositions.

Table 4 presents all gas-phase trace compounds measured in the torrefaction gas by micro-GC and in the flue gas by on-line gas analysis. There was no $\mathrm{CH}_{4}$ or $\mathrm{C}_{2} \mathrm{H}_{2}$ detected in the torrefaction gas (concentrations were below the detection limit of $0.001 \%$ ) which is consistent with a low torrefaction temperature or low torrefaction severity [39]. Flue gas measurements indicate the presence of small amounts of $\mathrm{NO}$ (in the range of $36-57 \mathrm{~cm}^{3} \mathrm{~m}^{-3}$ ) and $\mathrm{NO}_{2}$ (in the range of $0-2 \mathrm{~cm}^{3} \mathrm{~m}^{-3}$ ). NO is formed by reaction of oxygen with nitrogen in combustion air at high combustion temperatures (combustion temperature during these tests was ca. $870{ }^{\circ} \mathrm{C}$ ). $\mathrm{NO}_{2}$ is formed by further oxidation of NO.

\subsection{An optimised overall torrefaction system}

The data presented have been obtained from pilot scale torrefaction tests, but they can give valuable insights on how to optimise large-scale torrefaction and densification schemes as presented in Fig. 1. In this concept, biomass has to be pre-dried (here an initial moisture mass fraction is assumed of approx. 45\%) to a moisture mass fraction of $15-20 \%$ prior to torrefaction. The torrefaction reactor as well as the pre-drying unit require a substantial energy input for water evaporation. Therefore, not only proper design of these units, but also heat integration is essential in achieving high overall efficiencies and, thus, contributing to the economic viability of torrefaction.

Fig. 10 presents the calculated energy requirements and availability per torrefaction test. The calculations are based on mass and

Table 4

Trace compounds concentrations in torrefaction and flue gas (b.d.l. = below detection limit).

\begin{tabular}{|c|c|c|c|c|}
\hline Feedstock & Spruce wood & Ash wood & Ash wood & Willow wood \\
\hline Torrefaction temperature $/{ }^{\circ} \mathrm{C}$ & 260 & 250 & 265 & 260 \\
\hline \multicolumn{5}{|l|}{ Torrefaction gas $/ \mathrm{cm}^{3} \mathrm{~m}^{-3}$} \\
\hline $\mathrm{CH}_{4}^{\mathrm{a}}$ & b.d.l. & b.d.l. & b.d.l. & b.d.l. \\
\hline $\mathrm{H}_{2}{ }^{\mathrm{b}}$ & 600 & b.d.l. & 400 & b.d.l. \\
\hline $\mathrm{C}_{2} \mathrm{H}_{4}$ & 50 & 30 & 60 & 40 \\
\hline $\mathrm{C}_{2} \mathrm{H}_{6}$ & 30 & 40 & 90 & 40 \\
\hline $\mathrm{C}_{2} \mathrm{H}_{2}{ }^{\mathrm{a}}$ & b.d.l. & b.d.l. & b.d.l. & b.d.l. \\
\hline $\mathrm{H}_{2} \mathrm{~S}$ & 11 & 24 & 45 & 66 \\
\hline $\mathrm{C}_{6} \mathrm{H}_{6}$ & 129 & 129 & 199 & 117 \\
\hline $\mathrm{C}_{7} \mathrm{H}_{8}$ & 21 & 42 & 67 & 31 \\
\hline \multicolumn{5}{|l|}{ Flue gas $/ \mathrm{cm}^{3} \mathrm{~m}^{-3}$} \\
\hline NO & 36 & 38 & 49 & 57 \\
\hline $\mathrm{NO}_{2}$ & 1 & 1 & 0 & 2 \\
\hline
\end{tabular}

a Detection limit is $10 \mathrm{~cm}^{3} \mathrm{~m}^{-3}$.

b Detection limit is $100 \mathrm{~cm}^{3} \mathrm{~m}^{-3}$. 
energy balances (for 100\% balance closure) of the performed pilot torrefaction tests and extrapolated to an optimised and heatintegrated torrefaction system. In these calculations heat losses are not taken into account and the given values represent only the required and available energy streams in the process that have the potential to be utilised for heat integration. Table S1 of the supplementary material provides more information on the inputs and assumptions used for these calculations.

Fig. 10 verifies that pre-drying is the process unit that requires most energy input, amounting up to more than $70 \%$ of the total process energy requirements. Drying is assumed to take place in a flue gas dryer with energy requirements of $3.4 \mathrm{MJ} \mathrm{kg}^{-1}$ water evaporated and the moisture mass fraction of the wood is reduced from $45 \%$ to $15 \%$. The energy needed for torrefaction includes heating up of the biomass and $\mathrm{N}_{2}$ feeds to torrefaction temperature as well as evaporation of the remaining water in the wood. The heat of reaction for torrefaction of dry beech wood is in the range of $0.7 \mathrm{MJ} \mathrm{kg} \mathrm{kg}^{-1}$ endothermic to $-0.8 \mathrm{MJ} \mathrm{kg}^{-1}$ exothermic at torrefaction temperatures of $230{ }^{\circ} \mathrm{C}-300{ }^{\circ} \mathrm{C}[26,40]$. This is quite low compared to the other energy streams involved in the calculations (dry wood has an energy content of about $18 \mathrm{MJ} \mathrm{kg}^{-1}$ (LHV)) and is of the same order of magnitude as the error in the calculations of the calorific values. Therefore, the heat of reaction for torrefaction has not been taken into account in these calculations.

From the normalised mass and energy balances presented in Section 3.1 of this paper, the amount and calorific value of the torrefaction gas could be estimated. These calorific values were used to calculate the energy requirements and availability and include the incombustible fraction of the torrefaction gas, which consists of produced water, $\mathrm{CO}_{2}$ as well as $\mathrm{N}_{2}$. These three components can comprise a mass fraction of $56-64 \%$ of the torrefaction gas resulting in an overall calorific content of 9-10 $\mathrm{MJ} \mathrm{kg}^{-1}$ (on LHV basis) of the torrefaction gas stream.

In all cases shown in Fig. 10 there is additional energy input necessary to fulfill the total energy requirements. This extra energy input can be generated by combustion of additional wet biomass feedstock. Expressed by a mass fraction of the wet biomass input that is used for torrefaction it varies from $5.5 \%$ for ash wood torrefied at $265{ }^{\circ} \mathrm{C}-8.7 \%$ for spruce torrefied at $260{ }^{\circ} \mathrm{C}$.

Fig. 11 presents the theoretical overall thermal efficiency to convert the wet biomass input to a torrefied product, on an LHV and HHV basis (Fig. 11A). The efficiency definition used is as follows:

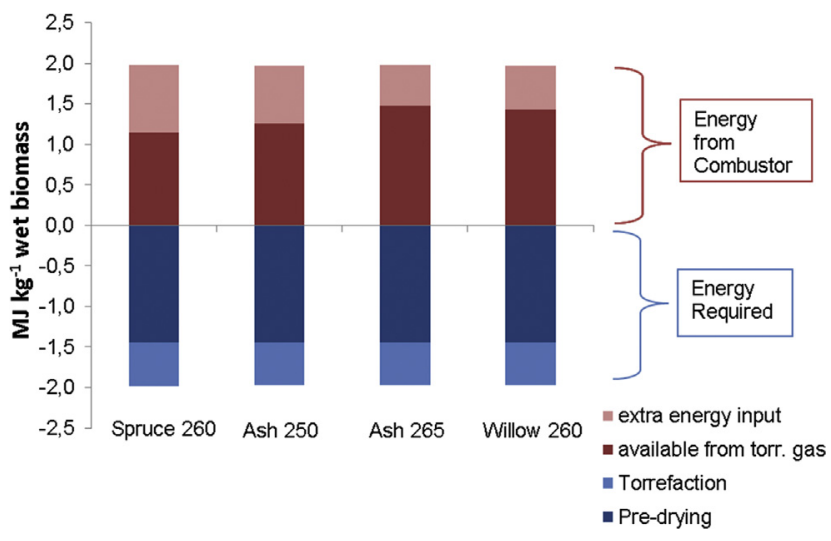

Fig. 10. Energy requirements (in light and dark blue) and availability (in light and dark red) in an overall torrefaction concept. The wet initial biomass is assumed to contain a mass fraction of $45 \%$ moisture (prior to pre-drying). The given values are calculated on LHV basis. (For interpretation of the references to colour in this figure legend, the reader is referred to the web version of this article.)
$\eta=\frac{E^{\text {OUT }}}{E^{I N}} 100 \%=\frac{E_{\text {torr }}}{E_{\text {wood }}^{\text {wet }}+E_{\text {input }}} 100 \%$

where $E_{\text {torr }}$ is the energy content of torrefied wood (here either on LHV or HHV basis), $\mathrm{E}^{\text {wet }}$ wood is the energy content of the wet, original wood and $E_{\text {input }}$ is the energy input that has to be provided to the system. All values are expressed in $\mathrm{MJ} \mathrm{kg}^{-1}$ wet wood, as presented in Fig. 10. In a heat-integrated system, this energy input equals the amount of extra energy needed on top of the energy content in the torrefaction gas in order to fulfill the energy requirements of the system. In a system without heat integration, where the torrefaction gases are just flared, the energy input equals the total energy needed for both pre-drying and torrefaction. Clearly, the latter is not attractive, but it is shown in Fig. 11B for comparison.

The efficiency values actually express a balance between the energy retained in the torrefied solid product and the energy that becomes available in the produced torrefaction gas. The efficiencies calculated for a heat-integrated system are $88-89 \%$. This is in good agreement with results presented by Bergman and Kiel [7] and Koppejan [41] in papers where a similarly integrated torrefaction concept has been examined. Therefore, experiment-based data and analyses can provide insights on optimal torrefaction conditions for individual biomass streams. The efficiency can be further increased when the location of the torrefaction plant permits the utilisation of residual heat from another process (e.g. waste incinerator or gas engine) for pre-drying the biomass. This is valid as long as the
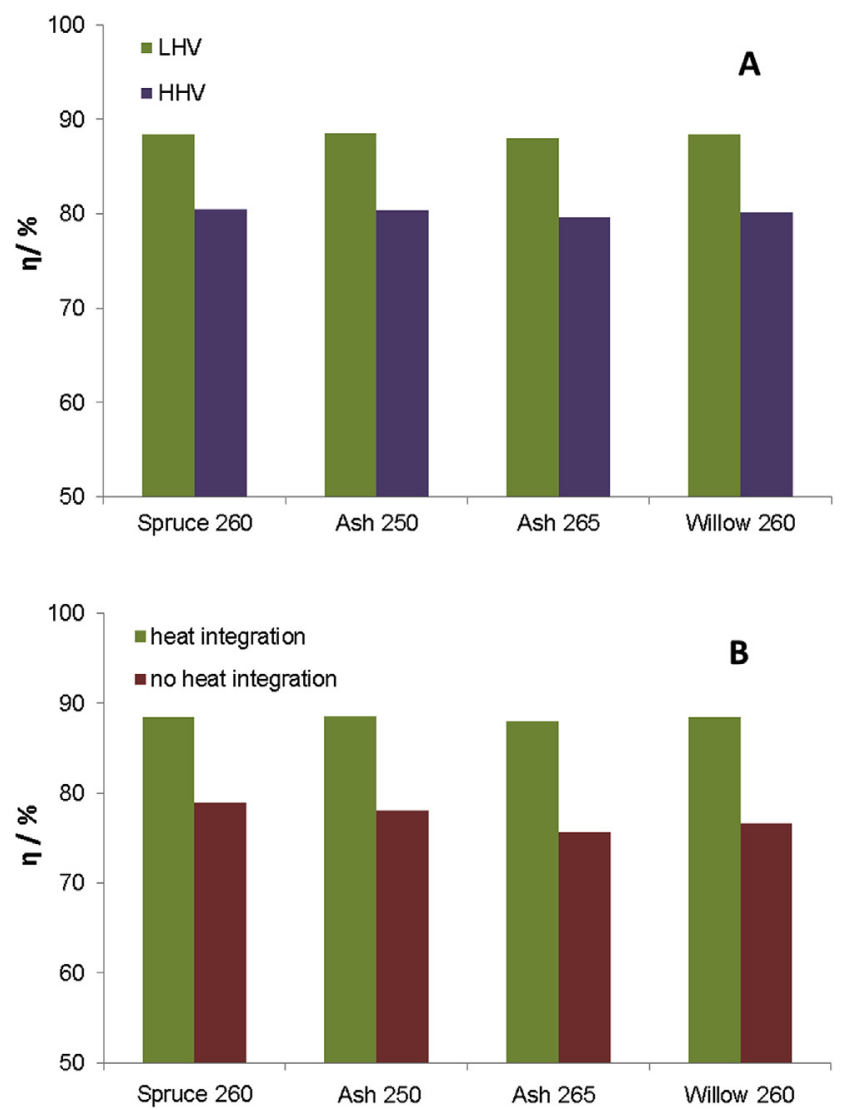

Fig. 11. Theoretical overall thermal efficiency expressed on (A) lower heating value basis (LHV) and higher heating value basis (HHV) and (B) lower heating value basis (LHV) with and without heat integration. The wet initial biomass is assumed to contain a mass fraction of $45 \%$ moisture (prior to pre-drying). 
residual heat can cover the otherwise extra energy input needed.

Besides heat, the overall torrefaction + densification process also utilises electricity, most of which is consumed in the densification step. Electricity use is not included in these calculations. Nevertheless, this would not significantly decrease the efficiency values presented since electricity use for e.g. pelletisation on this torrefaction scale would be only approx. $3.5 \%$ of the energy content of the wet ingoing biomass. This includes electricity used for milling, pelletisation, product cooling and steam generation. The sensible heat of the torrefied material before densification is not taken into account in the heat-integration calculations.

For the case of ash wood torrefied at $265{ }^{\circ} \mathrm{C}$ the data used in the calculations are included in Fig. S1 of the supplementary material in a simplified black box approach. In this case, the data are extrapolated to a 31.5 tonnes $\mathrm{h}^{-1}$ torrefaction scale.

Overall, these results show that a pilot plant is most suitable for: (1) the exploration of (new) feedstocks, since in a relatively short time various conditions can be tested at a low price, and (2) generating experimental data that provide valuable information for the design of full-scale plants. Moreover, the integrated torrefaction and densification concept shows very good potential for producing energy-dense solid bioenergy carriers in a sustainable way.

\section{Summary and conclusions}

This paper deals with the methods utilised to quantify process streams of a $50 \mathrm{~kg} \mathrm{~h}^{-1}$ torrefaction pilot plant located at ECN. The torrefaction tests described were conducted with spruce, ash and willow wood, which were torrefied at temperatures in the range of $250-265^{\circ} \mathrm{C}$. The experimental results were used to determine the mass and energy balances and to translate the values obtained into torrefaction process efficiencies of an optimised, heat-integrated torrefaction concept. The conclusions can be summarised as follows:

- The on- and off-line analytical methods utilised can be used effectively to provide sufficient information to determine mass and energy balances of a pilot test.

- The experimental data obtained from pilot scale provide valuable information for the design of full-scale plants and can be very well translated into large-scale energy management and efficiency.

- The theoretical overall thermal efficiency of an optimised, largescale, heat-integrated torrefaction system is $88-89 \%$ when a flue gas dryer is used for pre-drying the wood.

- Efficiency can be further increased when residual heat can be utilised to pre-dry the wet biomass.

\section{Acknowledgement}

Part of the work presented in this paper was conducted as part of the SECTOR and LogistEC projects, which have both received funding from the European Union's Seventh Programme for research, technological development and demonstration under grant agreement number 282826 (SECTOR) and FP7-311858 (LogistEC). Furthermore, the TKI Biobased Economy (TKI BBE) and the Netherlands Enterprise Agency (RVO) are gratefully acknowledged for their financial support of the Pre-treatment/INVENT project under agreement no. TKIBE01011.

\section{Appendix A. Supplementary data}

Supplementary data related to this article can be found at http:// dx.doi.org/10.1016/j.biombioe.2016.02.012.

\section{References}

[1] GEA, Global Energy Assessment - toward a Sustainable Future, 2012 (Cambridge University Press, Cambridge, UK and New York, NY, USA and the International Institute for Applied Systems Analysis, Laxenburg, Austria).

[2] J.H.A. Kiel, Torrefaction - a sustainable supply chain game changer, in: World Biofuels Markets Congress \& Exhibition, Rotterdam, The Netherlands, March 2013, pp. 12-14.

[3] M.C. Carbo, P.M.R. Abelha, A. van der Drift, A.H.H. Janssen, J.H.A. Kiel, C.F. Mourão Vilela, J.R. Pels, Characterisation of torrefied pellets, in: Workshop "Torrefaction of Biomass", Leeds, UK, April 2014, pp. 1-2.

[4] M.J.C. van der Stelt, H. Gerhauser, J.H.A. Kiel, K.J. Ptasinski, Biomass upgrading by torrefaction for the production of biofuels: a review, Biomass Bioenergy 35 (2011) 3748-3762.

[5] J.S. Tumuluru, S. Sokhansanj, J.R. Hess, C.T. Wright, R.D. Boardman, A review on biomass torrefaction process and product properties for energy applications, Ind. Biotechnol. 7 (5) (2011) 384-401.

[6] D. Ciolkosz, R. Wallace, A review of torrefaction for bioenergy feedstock production, Biofuels Bioprod. Biorefining 5 (2011) 317-329.

[7] P.C.A. Bergman, J.H.A. Kiel, Torrefaction for biomass upgrading, in: Proceedings of the 14th European Biomass Conference \& Exhibition, France, Paris, October 2005, pp. 17-21.

[8] A.H.H. Janssen, M.C. Carbo, Report on Requirements of End Users on Densified and Torrefied Materials, FP7 EU Project SECTOR, 2013 Dec, 18 p. Deliverable No. D 4.1.

[9] F. Shafizadeh, G.D. McGinnis, Chemical composition and thermal analysis of Cottonwood, Carbohydr. Res. 16 (1971) 273-277.

[10] D.R. Nhuchhen, P. Basu, B. Acharya, A comprehensive review on biomass torrefaction, Int. J. Renew. Energy Biofuels 2014 (2014) 56. Article ID 506376.

[11] K. Werner, L. Pommer, M. Broström, Thermal decomposition of hemicelluloses, J. Anal. Appl. Pyrolysis 110 (2014) 130-137.

[12] P. Basu, Biomass Gasification, Pyrolysis and Torrefaction: Practical Design and Theory, Academic Press, London, 2013, ISBN 978-0-12-396488-5.

[13] R.B. Bates, A.F. Ghoniem, Biomass torrefaction: modeling of reaction ther mochemistry, Bioresour. Technol. 134 (2013) 331-340.

[14] Y. Joshi, H. de Vries, T. Woudstra, W. de Jong, Torrefaction: unit operation modelling and process simulation, Appl. Therm. Eng. 74 (2015) 83-88.

[15] E. Peduzzi, G. Boissonnet, G. Haarlemmer, C. Dupont, F. Maréchal, Torrefaction modelling for lignocellulosic biomass conversion processes, Energy 70 (2014) 58-67.

[16] C. Park, U. Zahid, S. Lee, C. Han, Effect of process operating conditions in the biomass torrefaction: a simulation study using one-dimensional reactor and process model, Energy 79 (2015) 127-139.

[17] Y. Mei, R. Liu, Q. Yang, H. Yang, J. Shao, C. Draper, et al., Torrefaction of cedarwood in a pilot scale rotary kiln and the influence of industrial flue gas, Bioresour. Technol. 177 (2015) 355-360.

[18] M. Strandberg, I. Olofsson, L. Pommer, S. Wiklund-Lindström, K. Åberg, A. Nordin, Effects of temperature and residence time on continuous torrefaction of spruce wood, Fuel Process Technol. 134 (2015) 387-398.

[19] J. Karlsson, Evaluation of Torrefaction Pilot Plant in Klintehamn, Gotland, Master thesis, Lund University, Sweden, 2013.

[20] R. Wagenfuehr, C. von Scheiber, Holzatlas, VEB Fachbuchverlag, Germany 1974.

[21] F.J. Lemus, J. Gil, Cereal straw torrefaction: results on pilot plant test, in: Proceedings of the 21st European Biomass Conference \& Exhibition, Denmark Copenhagen, June 2013, pp. 3-7.

[22] N. Doassans-Carrère, S. Muller, M. Mitzkat, REVE-a new industrial technology for biomass torrefaction pilot studies, Fuel Process Technol. 126 (2014) $155-162$.

[23] B. Batidzirai, A.P.R. Mignot, W.B. Schakel, H.M. Junginger, A.P.C. Faaij, Biomass torrefaction technology: techno-economic status and future prospects, Energy 62 (2013) 196-214.

[24] F. Syu, P. Chiueh, Process simulation of rice straw torrefaction, Sustain Environ. Res. 22 (3) (2012) 177-183.

[25] W. Chen, M. Huang, J. Chang, C. Chen, W. Lee, An energy analysis of torrefaction for upgrading microalga residue as a solid fuel, Bioresour. Technol. 185 (2015) 285-293.

[26] D.A. Granados, H.I. Velásquez, F. Chejne, Energetic and exergetic evaluation of residual biomass in a torrefaction process, Energy 74 (2014) 181-189.

[27] M.J.C. Van der Stelt, Chemistry and Reaction Kinetics of Biowaste Torrefaction, PhD thesis, Technical University of Eindhoven, The Netherlands, 2010.

[28] T.A. Milne, A.H. Brennan, B.H. Glenn, Sourcebook of Methods of Analysis for Biomass Conversion and Biomass Conversion Processes. SERI/SP-220-3548 Solar Energy Research Institute, Golden, CO, February 1990.

[29] CEN/TS 15439, Biomass Gasification - Tar and Particles in Product Gases Sampling and Analysis, 2006.

[30] F. Patuzzi, D. Prando, M. Baratieri, Pyrolysis of common reed: thermal analysis of the feedstock and characterization of pyrolysis products, in: Proceedings of the 22nd European Biomass Conference \& Exhibition, Hamburg, Germany, June 2014, pp. 23-26.

[31] J.P.A. Neeft, E. Zuiver, B.F. van Egmond, ECN contribution to R\&D work supporting the development of a Guideline for sampling and analysis of tars in biomass producer gases. Sub-report to a joint BTG-ECN report to Novem. 2001 Oct. Report No.: ECN-CX-001-048. 
[32] J.P.A. Neeft, Rationale for setup of impinger train as used in the technical specification of sampling and analysis of tar and particles in the product gases of biomass gasification: Technical background document. 2005 Jan. 14 p.

[33] F.F. Felfli, C.A. Luengo, J.A. Suarez, P.A. Beaton, Wood briquette torrefaction, Energy Sustain. Dev. 9 (2005) 19-22.

[34] M.J. Prins, K.J. Ptasinski, F.J.J.G. Janssen, Torrefaction of wood part 2. Analysis of products, J. Anal. Appl. Pyrolysis 77 (2006) 35-40.

[35] H. Yang, R. Yan, H. Chen, D.H. Lee, C. Zheng, Characteristics of hemicellulose cellulose and lignin pyrolysis, Fuel 86 (2007) 1781-1788.

[36] K. Lê Thành, J.M. Commandré, J. Valette, G. Volle, M. Meyer, Detailed identification and quantification of the condensable species released during torrefaction of lignocellulosic biomasses, Fuel Process Technol. 139 (2015) 226-235.
[37] P. Lv, G. Almeida, P. Perré, TGA-FTIR analysis of torrefaction of lignocellulosic components (cellulose, xylan, lignin) in isothermal conditions over a wide arrange of time durations, BioResources 10 (2015) 4239-4251.

[38] J. Park, J. Meng, K.H. Lim, O.J. Rojas, S. Park, Transformation of lignocellulosic biomass during torrefaction, J. Anal. Appl. Pyrolysis 100 (2013) 199-206.

[39] R. Zanzi, D.T. Ferro, A. Torres, P.B. Soler, E. Bjornbom, Biomass torrefaction, in: 6th Asia-Pacific International Symposium on Combustion and Energy Utilization, Kuala Lumpur, Malaysia, May 2002, pp. 20-22.

[40] A. Ohliger, M. Förster, R. Kneer, Torrefaction of beechwood: a parametric study including heat of reaction and grindability, Fuel 104 (2013) 607-613.

[41] J. Koppejan, Status Overview of Torrefaction Technologies, IEA Task 32 report, Procede, Enschede, The Netherlands, 2012. 


\section{ECN}

Westerduinweg 3

P.O. Box 1

1755 LE Petten

1755 LG Petten

The Netherlands

The Netherlands

$\mathrm{T}+31885154949$

$F+31885158338$

info@ecn.nl

www.ecn.nl 